\title{
Pengaruh Media Audio Visual terhadap Pemahaman Maharoh Istima’ Bahasa Arab
}

\author{
Novi Rahmawati \\ Sekolah Tinggi Ilmu Tarbiyah Al Hidayah Tasikmalaya, Indonesia \\ rachmanovi1996@gmail.com
}

\begin{abstract}
Abstrak:
Artikel ini membahas pengaruh media audio visual pada maharoh istima' dimotivasi oleh pandangan mayoritas siswa tentang kesulitan belajar bahasa Arab. Keberhasilan belajar tidak lepas dari persiapan semua pihak. Guru harus mampu menumbuhkan motivasi belajar siswa. Model pembelajaran ini mengharuskan siswa untuk dapat mengucapkan mufrodat atau kalimat dan melatih keberanian untuk berbicara bahasa Arab di depan teman-teman mereka. Tujuan dari penelitian ini adalah: Untuk menjelaskan pemahaman maharoh istima', serta alat belajar, untuk mengetahui metode pembelajaran maharoh istima' menggunakan metode Audio Visual, untuk menemukan pembelajaran maharoh istima' kendala menggunakan audio visual. Desain penelitian ini menggunakan pendekatan kuantitatif dengan jenis penelitian korelasional. Populasi dalam penelitian ini adalah semua siswa kelas VIII MTs Persis 79 Rajapolah. Pengambilan sampel dalam penelitian ini menggunakan teknik non probability sampling dengan sampling jenuh, yaitu teknik pengambilan sampel jika semua anggota populasi. Sehingga dalam penelitian ini sampel yang digunakan adalah semua siswa kelas VIII. Pengumpulan data menggunakan tes yang berfungsi untuk menentukan nilai hasil belajar dalam pemecahan masalah. Dengan hasil sebagai berikut. (1) ada pengaruh media audio visual pada maharoh istima', hasilnya diperoleh dari nilai signifikansi kurang dari 0,05 , nilai signifikansi 0,000. Dengan demikian dapat disimpulkan bahwa ada pengaruh yang signifikan antara media audio visual pada maharoh istima' siswa.
\end{abstract}

Kata Kunci: Media Audio Visual, Maharoh Istima', Pendidikan Bahasa Arab 


\begin{abstract}
:
This article discusses the influence of audio visual media on maharoh istima 'is motivated by the views of the majority of students about the difficulty of learning Arabic. Learning success cannot be separated from the preparation of all parties. The teacher must be able to grow students' motivation to learn. This learning model requires students to be able to say mufrodat or sentences and train the courage to speak Arabic in front of their friends. The objectives of this study were: To explain the understanding of Maharoh istima' ', as well as the learning tools, to find out the learning method of Maharoh istima' using the Audio Visual method, to find Maharoh istima's learning constraints using audio visual.The design of this study uses a quantitative approach with a type of correlational research. The population in this study were all students of class VIII MTs Persis 79 Rajapolah. Sampling in this study used nonprobability sampling technique with saturated sampling, namely sampling technique if all members of the population. So that in this study the sample used was all class VIII students. Data collection uses a test that serves to determine the value of learning outcomes in problem solving. With the following results. (1) there is the influence of audio-visual media on maharoh istima ', the results are obtained from a significance value of less than 0.05 , a significance value of 0.000 . Thus it can be concluded that there is a significant influence between audio visual media on students' maharoh istima.
\end{abstract}

Keywords: Audio Visual Media, Maharoh istima', Arabic Language Education

\title{
Pendahuluan
}

Pendidikan merupakan sesuatu yang sangat penting bagi kehidupan manusia, karena pengaruhnya sangat besar terhadap kualitas hidup. Dalam kamus Besar Bahasa Indonesia Pusat Bahasa Departemen pendidikan, ${ }^{1}$ pengaruh adalah daya yang ada atau timbul dari sesuatu (orang, benda, dan lain-lain.) yang berkuasa atau yang berkekuatan, dari pengertian tersebut, manusia dapat dipengaruhi dari berbagai faktor untuk dapat memilih pendidikan yang baik. Seperti dalil dalam Alquran surat Al-Balad ayat 8-10 :

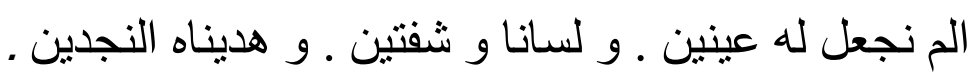

Artinya: "Bukankah Kami telah memberikan kepadanya dua mata, lidah, dua bibir dan Kami telah menunjukkan kepadanya dua jalan".

\footnotetext{
${ }^{1}$ Pusat Bahasa Departemen Pendidikan Nasional, Kamus Besar Bahasa Indonesia, (Jakarta : Balai Pustaka, 2006) hal. 865 .
} 
Maka untuk mencapai pendidikan yang efektif manusia dipengaruhi oleh pembelajaran yang harus disampaikan dengan cara yang menarik, baik guru yang kreatif, sarana yang menunjang, maupun metode pembelajaran yang tepat.

Metode menurut KBBI adalah cara teratur yang digunakan untuk melaksanakan suatu pekerjaan agar tercapai sesuai dengan yang dikehendaki; cara kerja yang bersistem untuk memudahkan pelaksanaan suatu kegiatan guna mencapai tujuan yang ditentukan. Dalam hal ini metode pembelajaran menentukan kualitas belajar siswa. Salah satu metode yang baik untuk belajar mengajar yaitu menggunakan media audio visual.

Media audio visual adalah media yang mempunyai unsur suara dan unsur gambar, jenis media ini mempunyai kemampuan yang lebih baik karena meliputi kedua jenis tersebut. Pengajaran audio visual ini penggunaan materi yang penerapannya melalui pandangan dan pendengaran serta tidak seluruhnya tergantung pada pemahaman kata atau simbol-simbol yang ada. Maka untuk memahami bahasa arab diperlukan kecakapan dalam berbicara dan mampu mendengar bahasanya dengan pemahaman yang baik.

Maharah istima (kemampuan mendengar) adalah salah satu dari kemampuan kebahasaan empat ${ }^{2}$ yang dipelajari mahasiswa pertama kali sebelum pembelajaran kemampuan kebahasaan empat yang lain. Menurut Hasan Sahatah, kemampuan mendengar yang baik sangat bermanfaat dalam memahami ide-ide pokok secara terperinci. ${ }^{3}$ Menurut Rusydi Ahmad Thuaimah seseorang yang memiliki kemampuan mendengar yang baik pasti ditunjang kemampuan antara lain: (a) memiliki pengetahuan bahasa Arab yang baik, tidak hanya dalam hal ilmu ashwat, kosakata dan struktur kalimat, tetapi juga aspek-aspek kebahasaan yang lain, (b) memiliki pengetahuan tentang tema-tema baru bahasa Arab, (c) memiliki pengetahuan tentang tujuan atau arah apa yang dibicarakan dalam tema tersebut, (d) memiliki pengalaman yang tentang berbicara bahasa Arab, (e) memiliki pengetahuan tentang bentuk-bentuk budaya yang berkaitan dengan bahasa Arab terutama yang memiliki arti khusus. Maka ini salah satu penunjang untuk memahami bahasa arab itu sendiri. ${ }^{4}$

Bahasa merupakan alat komunikasi yang sangat penting bagi seseorang, apa pun jabatan dan kedudukannya. Menurut Zulhannan, dalam bukunya yang berjudul "Teknik Pembelajaran Bahasa Arab Interaktif", dari rakyat kecil sampai rakyat publik figur, bahasa tetap menjadi

\footnotetext{
${ }^{2}$ Empat kemampuan bahasa tersebut adalah mendengar (istima) berbicara (kalam) membaca (qira'ah) dan menulis (kitabah)

${ }^{3}$ Hasan Sahatah. Ta'lim al-Lughoh al-'Arabiyah baina an-Nadhoriyah wa at- Tathbiq. (Bayrut: ad-Dar alMisriyah al-Libnaniyah, 1993) hal. 78.

${ }^{4}$ Rusydi Ahmad Thuaimah. al-Marja' fi Ta'lim al-Lughoh al-'Arabiyah li an- Natiqiina bi Lughot Ukhro. (Riyadh: Jami'ah Umm al-Quro Ma'had al-Lughoh al-'Arabiyah Wahdah al-Buhuts wa al-Manahij Silsilah Dirosat fi Ta'lim al-'Arabiyah, 1986) hal. 418.
} 
penentu kebijakannya. Fungsinya sangat banyak, di antaranya sebagai alat komunikasi, interaksi, penyampaian dan penerimaan informasi dan merupakan pengantar pola pikir orang tentang pemahaman berbagai kajian keilmuan. ${ }^{5}$

Bahasa Arab menjadi bahasa resmi di lebih dari 20 negara sekaligus bahasa ibu bagi lebih dari 300 juta orang. Bahasa Arab diucapkan di seluruh Timur Tengah, dari Maroko sampai ke Irak. Selain itu, karena bahasa Arab adalah bahasa Alquran dan Islam, maka bahasa ini pun dipahami oleh lebih dari 1,2 milyar orang di seluruh dunia. Maka bahasa Arab masuk dalam bahasa penting di dunia. Bahkan di negara-negara di mana bahasa Arab tidak menjadi bahasa resmi, orang berlomba untuk menguasai bahasa ini karena dianggap penting sebagai bahasa global.

Di luar semua itu, masyarakat Indonesia sebagai negeri dengan komunitas muslim terbesar di dunia memiliki keterikatan yang sangat kuat dengan bahasa Arab. Ada istilah mengatakan bahwa "bahasa adalah jendela ilmu pengetahuan", sementara Islam sebagai agama mayoritas di Indonesia lahir dari negeri berbahasa Arab. Oleh karena itu menguasai bahasa Arab dapat diartikan sebagai membuka jendela untuk menguasai ilmu-ilmu keislaman.

Kemahiran berbahasa Arab adalah merupakan salah satu jenis kemampuan yang ingin dicapai dalam pengajaran berbahasa Arab, karena bahasa Arab merupakan sarana utama untuk berkomunikasi dengan orang Arab dan memahami buku atau kitab yang berbahasa Arab. Maka diperlukan pengoptimalan belajar dan mengajar bahasa Arab di dalam instansi pendidikan formal maupun nonformal. Untuknya, upaya-upaya pengoptimalan kegiatan belajar mengajar sangat tepat dilakukan demi meningkatkan kualitas pendidikan bahasa Arab. Untuk itu, diperlukan sekali pembelajaran yang efektif yang merupakan suatu upaya untuk mengetahui berhasil tidaknya pelaksanaan pembelajaran bahasa, khususnya bahasa Arab baik dari segi proses maupun hasil.

Menurut Tayas Yusuf dan Saiful Anwar, peran seorang guru tidak cukup sebagai pengajar saja, namun harus berperan sebagai pakar atau ahli bahasa yang mampu menguasai perbendaharan bahasa Arab dan retorikanya. Hal ini sangat berpengaruh atas kesuksesan peserta didik dan tujuan instansi pendidikan bahasa. Upaya yang dapat dilakukan berupa pengadaan pusat pelatihan (Lab Bahasa), media audio visual dan buku-buku karya ilmiah yang menyajikan bahasa Arab yang mudah. ${ }^{6}$

Bahasa Arab sebagai bahasa asing di Indonesia seyogyanya dipelajari secara seksama untuk mencapai kompetensi kebahasaan melalui metode dan teknik yang menarik minat pembelajar.

\footnotetext{
${ }^{5}$ Zulhannan, Teknik Pembelajaran Bahasa Arab Interaktif, (Jakarta:, PT Raja Grafindo Persada, 2014) hal. 5.

${ }^{6}$ Tayas Yusuf dan Saiful Anwar. Metodologi Pembelajaran dan Bahasa Arab (Jakarta:, PT. Grafindo Persada, 1995) hal. 188-189
} 
Abdul Hamid, et. al., berkata dalam bukunya "Pembelajaran Bahasa Arab, Pendekatan, Metode, Strategi, Materi dan Media, kompetensi kebahasaan dimaksud meliputi empat keterampilan berbahasa yaitu keterampilan menyimak (maharah al-i stima'), keterampilan bercakap (maharah al-kalam), keterampilan membaca (maharah al-qiraah), dan keterampilan menulis (maharah al-kitabah). ${ }^{7}$

Keterampilan yang pertama dibangun dalam pembelajaran bahasa adalah menyimak (istima'), karena melalui keterampilan ini para pembelajar dapat menguasai keterampilan lainnya yaitu kalam, qiraah dan kitabah. Istima' mengilhami orang mengenal mufradat, bentuk-bentuk jumlah dan tarakib. ${ }^{8}$

Salah satu inovasi pembelajaran yang menarik adalah melalui media audio-visual. Proses menyimak dan memperhatikan melalui metode ini dilakukan sambil mengulang-ulangi lafadzlafadz kosa kata yang dianggap sulit hingga mahasiswa dapat memahami kosa kata dan konteks pembicaraan yang dituturkan. Penggunaan media audio-visual akan menciptakan nuansa yang berbeda sehingga bisa menghindarkan mereka dari kejenuhan dalam belajar bahasa Arab.

Artikel ini akan menjawab pertanyaan: (1) Apa pentingnya media audio visual dalam perspektif pembelajaran Maharoh Al-Istima' bahasa Arab? (2) Apakah terdapat pengaruh menggunakan media audio visual terhadap pemahaman Maharoh Al-Istima' siswa? (3) Apa saja kendalakendala yang dihadapi guru dan siswa dalam menggunakan media audio visual terhadap pembelajaran Maharoh Al-Istima'?

\section{Media Audio Visual}

Secara harfiah media memiliki arti perantara atau pengantar. Association For Education And Communication Teknologi (AECT) mendefinisikan media yaitu segala bentuk yang dipergunakan untuk suatu penyaluran informasi. Menurut Education (NEA) mendefinisikan sebagai benda yang dapat dimanipulasikan, dilihat, didengar, dibaca atau dibicarakan beserta instrumen yang dipergunakan dengan baik dalam kegiatan belajar mengajar dan dapat mempengaruhi efektivitas program instruksional.

Audio Visual adalah gabungan dari audio dan visual, audio adalah suara yang dapat didengar sedangkan visual adalah yang dapat dilihat. Menurut Syaiful Bahri dan Aswin Zain audio visual adalah media yang mempunyai unsur-unsur suara dan unsur gambar. ${ }^{9}$ Sedangkan Azhar Arsyad berpendapat bahwa audio visual adalah cara menghasilkan atau menyampaikan materi

\footnotetext{
${ }^{7}$ Abdul Hamid et al. .Pembelajaran Bahasa Arab: Pendekatan, Metode, Strategi, Materi, dan Media (Malang: UIN-Malang Press, 2008) hal. 37.

${ }^{8}$ Abdul Hamid et al. .Pembelajaran Bahasa Arab ... hal. 37.

${ }^{9}$ Syaiful Bahri dan Zain Aswin. Strategi Belajar Mengajar (Jakarta: Ciputat Press, 1997) hal. 141.
} 
dengan menggunakan mesin-mesin mekanis dan elektronik untuk menyampaikan pesan-pesan audio dan visual. ${ }^{10}$ Maka dapat disimpulkan bahwa media audio visual adalah alat perantara yang digunakan untuk menyampaikan konsep pembelajaran yang dapat ditangkap oleh indra pendengaran dan pandangan sehingga memudahkan siswa dalam memahami materi yang diajukan.

\section{Pemahaman Maharoh istima'}

Istima' secara bahasa berasal dari bahasa arab yang berarti mendengarkan atau menyimak. Menurut Imam Makruf yang dikutip oleh Cahya Edi Setyawan, Istima' secara istilah adalah:

"Sarana pertama yang digunakan manusia untuk berhubungan dengan sesama manusia dalam tahapan-tahapan tertentu, melalui menyimak kita mengenal mufrodat, bentukbentuk jumlah dan tarakib." 11

Sesungguhnya proses menyimak tidak sekadar mendengar, tetapi lebih dari itu, yaitu mendengar dengan memusatkan perhatian kepada objek yang disimak. Proses menyimak merupakan kegiatan mendengarkan yang disengaja dalam rangka mencapai maksud-maksud tertentu. Maksud-maksud tersebut misalnya, untuk tujuan belajar, mengapresiasi sebuah karya, mendapatkan informasi khusus, memecahkan masalah, atau untuk memahami aspek-aspek sebuah bahasa. ${ }^{12}$

Menurut Ali Ahmad Madkur Istima' merupakan proses yang rumit dan memiliki beberapa unsur sebagai berikut:

$$
\text { للمادة المسموعة هو التعرف على الاصوات و الفهم و التحليل و التفسير و التطبيق و النقد والتقويم }
$$

"Istima' adalah mengenali suara, memahami,menganalisis, menginterpretasikan, mempraktikan, mengkritik dan mngevaluasi materi yang didengarkan". ${ }^{13}$

\section{Hipotesis Penelitian}

Dengan hipotesis awal sebagai berikut:

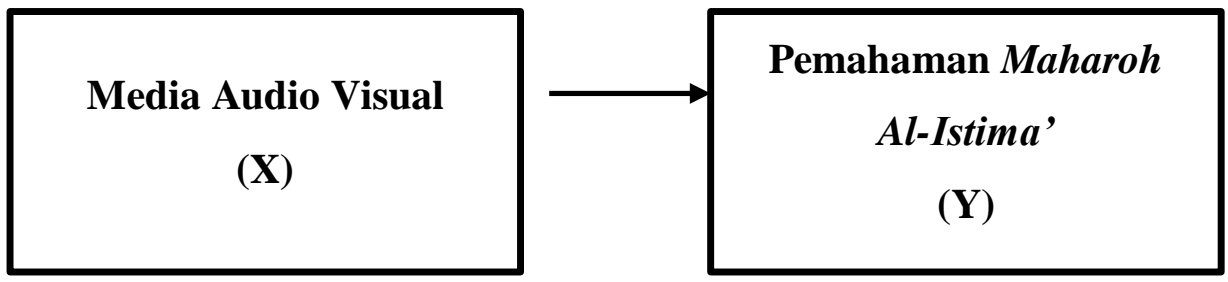

\footnotetext{
${ }^{10}$ Arsyad Azhar. Media Pembelajaran (Jakarta: Raja Grafindo Persada, 2010) hal. 89.

${ }^{11}$ Cahya Edi Setyawan. "Konsep Landasan Teori Dan Rancangan Silabus Pembelajaran Maharah Istima Di Perguruan Tinggi" Jurnal Komunikasi dan Pendidikan Islam, Volume 7, Nomor 1, Juni 2018. hal. 162.

12 W. Gulo, Strategi Belajar Mengajar. (Jakarta: Grasindo, 2002)

13 Ali Ahmad Madkur. Tadris Funun al-Lughah al-Arabiyah (Kairo: Dar el-Fikr al-'Araby, 2006) hal. 84.
} 
Keterangan:

Pengaruh variabel $\mathrm{X}$ terhadap variabel $\mathrm{Y}$

H1 = Pengaruh media audio visual terhadap pemahaman maharoh al-istima'

\section{Desain Penelitian}

Penelitian ini menggunakan metode kuantitatif dengan tipe metode korelasional. di MTs Persatuan Islam 79 Rajapolah tepat di Jalan Ciberekah Desa Manggungjaya, Kecamatan Rajapolah ,Kabupaten Tasikmalaya. Populasi dalam penelitian ini adalah siswa kelas VIII MTs Persatuan Islam 79 Rajapolah Tahun Ajaran 2018/2019 yang berjumlah 24 siswa. Data dihimpun dengan tiga cara yaitu wawancara, tes soal dan dokumentasi.

\section{Uji Coba Instrumen}

Instrumen yang digunakan dalam penelitian ini berupa soal-soal. Adapun prosedur yang dilakukan dalam penyusunan instrumen ini yaitu:

1. Perencanaan

Tahap perencanaan dilakukan oleh peneliti dan guru bidang mata pelajaran untuk menentukan materi pokok yang akan diteliti dan bentuk-bentuk soal yang akan diajukan.

2. Uji validitas

Pada tahapan ini peneliti memulai dengan harga korelasi setiap butir alat ukur dengan rumus Pearson/Product Moment, yaitu:

$$
r_{x y}=\frac{N \sum x y-\left(\sum x\right)\left(\sum y\right)}{\sqrt{(n} \sum X^{2}-\left(\sum X\right)^{2} \cdot\left(n \sum Y^{2}-\left(\sum Y\right)^{2}\right)}
$$

Keterangan :

rxy= koefisien korelasi

$\mathrm{X}=$ skor Soal butiur soal

$\mathrm{Y}=$ jumlah skor total tiap soal

$\mathrm{n}=$ jumlah responden $^{14}$

Pada tahap berikutnya peneliti melakukan perhitungan dengan uji t dengan rumus:

$\mathrm{t}_{\text {hitung }}=\frac{r \sqrt{n-2}}{\sqrt{1-r^{2}}}$

3. Uji Realibilitas

Analisis reliabilitas tes pada penelitian ini menggunakan rumus Cronbach's Alpha $(\alpha)$ :

$$
r_{11}=\left(\frac{n}{n-1}\right)\left(1-\frac{\sum s_{i}^{2}}{S_{t}^{2}}\right)
$$

Keterangan:

${ }^{14}$ Arikunto dan Suharismi, Prosedur Penelitian Suatu Pendekatan Praktek (Jakarta: Rineka Cipta, 2008) hal. 72. 
r11 : Realibilitas instrumen

$\mathrm{n}=$ banyaknya butir pertanyaan

$\Sigma \mathrm{S} \_\mathrm{i}^{\wedge} 2=$ Jumlah varians item

$\mathrm{S} \_\mathrm{t}^{\wedge} 2=$ Varians total

4. Tingkat Kesukaran Soal

Rumus yang digunakan untuk instrument berupa soal essay adalah:

$T K=\frac{\bar{X}}{S M I}$

Keterangan:

TK = Indeks tingkat kesukaran

$\mathrm{X}^{-} \quad=$ Nilai rata-rata tiap butir soal

SMI $=$ Skor Maksimun Ideal $^{15}$

5. Uji Wilcoxon

Uji ini digunakan untuk menguji signifikansi hipotesis perbandingan dua sampel yang saling berkorelasi bila persyaratan distribusi normal tidak terpenuhi, atau jika data yang diolah termasuk kelompok data berbentuk ordinal.

Konsep Dasar Uji Wilcoxon :

a. Uji Wilcoxon bertujuan untuk mengetahui ada tidaknya perbedaan rata-rata dua sampel yang saling berpasangan.

b. Data penelitian yang digunakan dalam uji Wilcoxon idealnya adalah data berskala ordinal atau interval.

c. Uji Wilcoxon merupakan bagian dari statistic non parametric, maka dalam uji Wilcoxon tidak diperlukan data penelitian yang berdistribusi normal.

d. Uji Wilcoxon digunakan sebagai alternatif dari uji paired sample $t$ test, jika data penelitian tidak berdistribusi normal.

\section{Hasil Penelitian}

\section{Uji Validitas}

Tabel 1. Hasil Data Pertanyaan Soal Bahasa Arab Menggunakan Media Audio Visual

\begin{tabular}{|c|c|c|c|c|c|c|c|c|c|c|c|c|c|c|c|c|c|c|c|c|c|c|}
\hline \multirow{2}{*}{ NO } & \multirow{2}{*}{ Siswa } & \multicolumn{21}{|c|}{ Soal } \\
\hline & & 1 & 2 & 3 & 4 & 5 & 6 & 7 & 8 & 9 & 10 & 11 & 12 & 13 & 14 & 15 & 16 & 17 & 18 & 19 & 20 & Jumlah \\
\hline 1. & Dela & 3 & 3 & 2 & 3 & 2 & 3 & 4 & 4 & 4 & 4 & 4 & 3 & 4 & 4 & 3 & 4 & 4 & 3 & 4 & 4 & 69 \\
\hline 2. & Didan & 2 & 3 & 4 & 2 & 3 & 3 & 3 & 3 & 3 & 2 & 2 & 3 & 3 & 3 & 3 & 3 & 2 & 2 & 3 & 2 & 54 \\
\hline 3. & Didin & 3 & 4 & 4 & 4 & 3 & 4 & 3 & 4 & 4 & 4 & 4 & 4 & 4 & 3 & 4 & 4 & 3 & 4 & 4 & 4 & 75 \\
\hline 4. & Diki & 3 & 3 & 4 & 3 & 3 & 3 & 4 & 4 & 4 & 3 & 3 & 4 & 3 & 3 & 3 & 3 & 4 & 4 & 4 & 4 & 69 \\
\hline 5. & Fikri & 2 & 1 & 2 & 2 & 3 & 3 & 3 & 3 & 3 & 2 & 2 & 1 & 2 & 3 & 3 & 3 & 4 & 3 & 3 & 3 & 51 \\
\hline 6. & Hasni & 3 & 4 & 3 & 3 & 4 & 3 & 4 & 3 & 4 & 3 & 3 & 3 & 3 & 3 & 4 & 3 & 4 & 3 & 4 & 4 & 68 \\
\hline 7. & Imam & 3 & 3 & 4 & 2 & 2 & 3 & 3 & 3 & 3 & 3 & 2 & 3 & 3 & 3 & 4 & 3 & 2 & 2 & 3 & 3 & 57 \\
\hline
\end{tabular}

${ }^{15}$ Arikunto dan Suharismi, Prosedur Penelitian Suatu Pendekatan Praktek ... hal. 207. 
Pengaruh Media Audio Visual Terhadap Pemahaman Maharoh Istima' Bahasa Arab

\begin{tabular}{|c|c|c|c|c|c|c|c|c|c|c|c|c|c|c|c|c|c|c|c|c|c|c|}
\hline 8. & Irfan & 2 & 2 & 4 & 3 & 3 & 3 & 3 & 3 & 2 & 3 & 2 & 2 & 2 & 4 & 3 & 3 & 2 & 3 & 3 & 3 & 55 \\
\hline 9. & Jamil & 3 & 3 & 3 & 4 & 3 & 3 & 4 & 4 & 3 & 3 & 3 & 3 & 3 & 3 & 3 & 4 & 4 & 4 & 4 & 4 & 68 \\
\hline 10. & Jasmin & 2 & 2 & 4 & 2 & 3 & 3 & 2 & 3 & 3 & 3 & 3 & 3 & 3 & 4 & 3 & 3 & 4 & 3 & 3 & 4 & 60 \\
\hline 11. & Khusi & 3 & 4 & 4 & 4 & 4 & 3 & 3 & 3 & 3 & 4 & 3 & 4 & 3 & 3 & 4 & 3 & 4 & 3 & 3 & 3 & 68 \\
\hline 12. & Laisa & 4 & 4 & 3 & 3 & 4 & 3 & 4 & 3 & 3 & 3 & 4 & 4 & 3 & 3 & 4 & 4 & 4 & 4 & 4 & 4 & 72 \\
\hline 13. & Nabil & 2 & 2 & 3 & 3 & 3 & 3 & 3 & 3 & 2 & 2 & 3 & 2 & 2 & 2 & 3 & 3 & 2 & 2 & 3 & 3 & 51 \\
\hline 14. & Nurlaila & 4 & 3 & 4 & 3 & 3 & 3 & 3 & 4 & 3 & 3 & 4 & 3 & 4 & 4 & 3 & 3 & 3 & 4 & 3 & 2 & 66 \\
\hline 15. & Paldi & 2 & 2 & 3 & 3 & 4 & 3 & 3 & 3 & 3 & 3 & 3 & 4 & 4 & 3 & 4 & 3 & 2 & 2 & 3 & 2 & 59 \\
\hline 16. & Rihma & 3 & 3 & 2 & 3 & 2 & 3 & 4 & 4 & 3 & 3 & 3 & 3 & 3 & 3 & 2 & 3 & 4 & 4 & 4 & 4 & 63 \\
\hline 17. & Rubby & 2 & 3 & 3 & 3 & 4 & 3 & 2 & 3 & 3 & 4 & 3 & 3 & 3 & 3 & 3 & 3 & 2 & 2 & 3 & 2 & 57 \\
\hline 18. & Salman & 4 & 4 & 4 & 4 & 4 & 4 & 3 & 4 & 4 & 4 & 4 & 4 & 4 & 4 & 4 & 4 & 3 & 4 & 4 & 4 & 78 \\
\hline 19. & Salwa & 3 & 4 & 3 & 3 & 3 & 3 & 3 & 4 & 3 & 3 & 3 & 4 & 3 & 4 & 3 & 3 & 3 & 4 & 3 & 3 & 65 \\
\hline 20. & Selpi & 2 & 2 & 3 & 3 & 2 & 3 & 2 & 2 & 3 & 2 & 2 & 3 & 3 & 4 & 4 & 3 & 2 & 2 & 3 & 2 & 52 \\
\hline 21. & Siti & 3 & 3 & 2 & 3 & 2 & 3 & 4 & 4 & 3 & 3 & 3 & 3 & 2 & 4 & 3 & 3 & 4 & 4 & 3 & 3 & 62 \\
\hline 22. & Srilasmi & 3 & 3 & 4 & 3 & 2 & 3 & 4 & 4 & 3 & 3 & 3 & 3 & 2 & 4 & 4 & 3 & 4 & 4 & 3 & 3 & 65 \\
\hline 23. & Zulfa & 4 & 4 & 4 & 4 & 3 & 4 & 4 & 4 & 3 & 4 & 4 & 4 & 4 & 4 & 4 & 4 & 3 & 4 & 4 & 4 & 77 \\
\hline 24. & Yaris & 2 & 2 & 3 & 2 & 3 & 3 & 3 & 3 & 3 & 3 & 3 & 2 & 2 & 3 & 3 & 3 & 3 & 3 & 3 & 2 & 54 \\
\hline & Jumlah & 67 & 71 & 79 & 72 & 72 & 75 & 78 & 82 & 75 & 74 & 73 & 75 & 72 & 81 & 81 & 78 & 76 & 77 & 81 & 76 & 1515 \\
\hline
\end{tabular}

Tabel 2. Rekapitulasi Perhitungan Validitas Butir Soal Menggunakan Media

\begin{tabular}{|c|c|c|c|c|}
\hline Soal & $\begin{array}{c}\text { Koef. } \\
\text { Korelasi }\end{array}$ & $\mathbf{t}_{\text {hitung }}$ & $\boldsymbol{t}_{\text {tabel }}$ & Keterangan \\
\hline 1 & 0.851 & 9.461 & 2.0739 & Valid \\
\hline 2 & 0.823 & 8.450 & 2.0739 & Valid \\
\hline 3 & 0.262 & 1.586 & 2.0739 & Tidak Valid \\
\hline 4 & 0.724 & 6.131 & 2.0739 & Valid \\
\hline 5 & 0.249 & 1.504 & 2.0739 & Tidak Valid \\
\hline 6 & 0.638 & 4.836 & 2.0739 & Valid \\
\hline 7 & 0.512 & 3.481 & 2.0739 & Valid \\
\hline 8 & 0.670 & 5.275 & 2.0739 & Valid \\
\hline 9 & 0.629 & 4.722 & 2.0739 & Valid \\
\hline 10 & 0.728 & 6.204 & 2.0739 & Valid \\
\hline 11 & 0.806 & 7.957 & 2.0739 & Valid \\
\hline 12 & 0.743 & 6.476 & 2.0739 & Valid \\
\hline 13 & 0.632 & 4.756 & 2.0739 & Valid \\
\hline 14 & 0.275 & 1.670 & 2.0739 & Tidak Valid \\
\hline 15 & 0.367 & 2.305 & 2.0739 & Valid \\
\hline 16 & 0.723 & 6.104 & 2.0739 & Valid \\
\hline 17 & 0.473 & 3.138 & 2.0739 & Valid \\
\hline 18 & 0.728 & 6.209 & 2.0739 & Valid \\
\hline 19 & 0.760 & 6.836 & 2.0739 & Valid \\
\hline 20 & 0.679 & 5.399 & 2.0739 & Valid \\
\hline & & & & \\
\hline
\end{tabular}


Novi Rahmawati

Dari tabel 1 dan 2 uji validitas soal menggunakan MS.Excel dilakukan pada 24 siswa, untuk hasil uji variabel x yaitu 20 soal pertanyaan. Soal yang dinyatakan valid 17 soal pertanyaan dan tidak valid 3 soal pertanyaan.

Untuk skor jawaban dan hasil rekapitulasi siswa terhadap variabel y adalah pada tabel 3 dan 4 .

Tabel 3. Data Hasil Soal Bahasa Arab Maharoh istima'

\begin{tabular}{|c|c|c|c|c|c|c|c|c|c|c|c|c|c|c|c|c|c|c|c|c|c|c|}
\hline \multirow{2}{*}{$\begin{array}{l}\mathbf{N} \\
\mathbf{O}\end{array}$} & \multirow{2}{*}{ Siswa } & \multicolumn{20}{|c|}{ Soal } & \multirow{2}{*}{$\begin{array}{c}\text { Juml } \\
\text { ah }\end{array}$} \\
\hline & & 1 & 2 & 3 & 4 & 5 & 6 & 7 & 8 & 9 & 10 & 11 & 12 & 13 & 14 & 15 & 16 & 17 & 18 & 19 & 20 & \\
\hline 1 & Dela & 3 & 3 & 2 & 3 & 2 & 3 & 4 & 4 & 4 & 3 & 2 & 3 & 3 & 4 & 3 & 4 & 4 & 3 & 4 & 4 & 65 \\
\hline 2 & Didan & 2 & 3 & 4 & 2 & 3 & 3 & 2 & 2 & 3 & 2 & 2 & 3 & 2 & 2 & 3 & 3 & 2 & 2 & 3 & 2 & 50 \\
\hline 3 & Didin & 3 & 4 & 4 & 3 & 3 & 4 & 3 & 4 & 4 & 4 & 3 & 4 & 4 & 3 & 3 & 4 & 3 & 4 & 4 & 4 & 72 \\
\hline 4 & Diki & 3 & 3 & 4 & 3 & 2 & 3 & 4 & 4 & 3 & 3 & 3 & 4 & 2 & 3 & 3 & 3 & 4 & 4 & 4 & 3 & 65 \\
\hline 5 & Fikri & 2 & 1 & 2 & 1 & 3 & 3 & 2 & 3 & 3 & 2 & 2 & 1 & 2 & 1 & 3 & 3 & 2 & 3 & 3 & 2 & 44 \\
\hline 6 & Hasni & 3 & 3 & 3 & 3 & 4 & 3 & 4 & 3 & 3 & 3 & 3 & 3 & 3 & 3 & 4 & 3 & 4 & 3 & 3 & 3 & 64 \\
\hline 7 & Imam & 2 & 3 & 4 & 2 & 2 & 3 & 2 & 2 & 3 & 2 & 2 & 3 & 2 & 3 & 2 & 3 & 2 & 2 & 3 & 2 & 49 \\
\hline 8 & Irfan & 2 & 2 & 4 & 2 & 3 & 3 & 2 & 2 & 2 & 2 & 2 & 2 & 2 & 4 & 3 & 3 & 2 & 2 & 2 & 2 & 48 \\
\hline 9 & Jamil & 3 & 3 & 3 & 2 & 3 & 2 & 4 & 4 & 3 & 3 & 3 & 3 & 3 & 2 & 3 & 2 & 4 & 4 & 3 & 3 & 60 \\
\hline 10 & Jasmin & 2 & 2 & 4 & 2 & 3 & 3 & 2 & 3 & 3 & 2 & 2 & 2 & 2 & 4 & 3 & 3 & 2 & 3 & 3 & 2 & 52 \\
\hline 11 & Khusi & 3 & 4 & 3 & 3 & 4 & 3 & 3 & 3 & 3 & 3 & 3 & 4 & 3 & 3 & 4 & 3 & 3 & 3 & 3 & 3 & 64 \\
\hline 12 & Laisa & 3 & 3 & 3 & 3 & 4 & 3 & 4 & 3 & 3 & 3 & 3 & 3 & 3 & 3 & 4 & 3 & 4 & 3 & 3 & 3 & 64 \\
\hline 13 & Nabil & 2 & 2 & 2 & 3 & 3 & 3 & 2 & 3 & 2 & 2 & 2 & 2 & 2 & 2 & 3 & 3 & 2 & 2 & 3 & 2 & 47 \\
\hline 14 & $\begin{array}{l}\text { Nurlail } \\
\mathrm{a}\end{array}$ & 3 & 3 & 4 & 3 & 3 & 3 & 3 & 4 & 3 & 3 & 3 & 3 & 3 & 3 & 3 & 3 & 3 & 4 & 2 & 2 & 61 \\
\hline 15 & Paldi & 2 & 2 & 3 & 3 & 2 & 3 & 2 & 2 & 3 & 2 & 3 & 3 & 2 & 3 & 3 & 3 & 2 & 2 & 3 & 2 & 50 \\
\hline 16 & Rihma & 3 & 3 & 2 & 3 & 2 & 3 & 4 & 4 & 3 & 3 & 3 & 3 & 2 & 3 & 2 & 3 & 4 & 4 & 3 & 3 & 60 \\
\hline 17 & Rubby & 2 & 3 & 2 & 3 & 2 & 3 & 2 & 2 & 3 & 4 & 3 & 3 & 2 & 3 & 3 & 3 & 2 & 2 & 3 & 2 & 52 \\
\hline 18 & Salman & 4 & 4 & 4 & 4 & 4 & 4 & 4 & 4 & 3 & 4 & 4 & 4 & 4 & 4 & 4 & 4 & 4 & 4 & 3 & 4 & 78 \\
\hline 19 & Salwa & 3 & 4 & 3 & 3 & 3 & 3 & 3 & 4 & 3 & 3 & 3 & 4 & 3 & 3 & 3 & 3 & 3 & 4 & 3 & 3 & 64 \\
\hline 20 & Selpi & 2 & 2 & 3 & 3 & 2 & 3 & 2 & 2 & 3 & 2 & 2 & 3 & 2 & 3 & 3 & 3 & 2 & 2 & 3 & 2 & 49 \\
\hline 21 & Siti & 3 & 3 & 2 & 3 & 2 & 3 & 4 & 4 & 3 & 3 & 3 & 3 & 2 & 4 & 2 & 3 & 4 & 4 & 3 & 3 & 61 \\
\hline 22 & $\begin{array}{l}\text { Srilasm } \\
\mathrm{i} \\
\end{array}$ & 3 & 3 & 2 & 3 & 2 & 3 & 4 & 4 & 3 & 3 & 3 & 3 & 2 & 4 & 3 & 3 & 4 & 4 & 3 & 3 & 62 \\
\hline 23 & Zulfa & 4 & 4 & 4 & 4 & 4 & 4 & 4 & 4 & 3 & 4 & 4 & 4 & 4 & 4 & 3 & 4 & 3 & 4 & 4 & 4 & 77 \\
\hline 24 & Yaris & 2 & 2 & 2 & 2 & 3 & 3 & 2 & 3 & 3 & 2 & 3 & 2 & 2 & 3 & 3 & 3 & 3 & 3 & 3 & 2 & 51 \\
\hline & $\begin{array}{l}\text { Jumla } \\
\text { h }\end{array}$ & 64 & 69 & 73 & 66 & 68 & 74 & 72 & 77 & 72 & 67 & 66 & 72 & 61 & 74 & 73 & 75 & 72 & 75 & 74 & 65 & 1409 \\
\hline
\end{tabular}

Tabel 4. Rekapitulasi Perhitungan Validitas Maharoh istima'

\begin{tabular}{|c|c|c|c|c|}
\hline Soal & $\begin{array}{c}\text { Koef. } \\
\text { Korelasi }\end{array}$ & $\boldsymbol{t}_{\text {hitung }}$ & $\boldsymbol{t}_{\text {tabel }}$ & Keterangan \\
\hline 1 & 0.957 & 10.343 & 2.0739 & Valid \\
\hline 2 & 0.842 & 9.100 & 2.0739 & Valid \\
\hline 3 & 0.274 & 1.661 & 2.0739 & Tidak Valid \\
\hline 4 & 0.743 & 6.473 & 2.0739 & Valid \\
\hline 5 & 0.415 & 2.659 & 2.0739 & Valid \\
\hline
\end{tabular}




\begin{tabular}{|c|c|c|c|c|}
\hline 6 & 0.558 & 3.920 & 2.0739 & Valid \\
\hline 7 & 0.808 & 7.996 & 2.0739 & Valid \\
\hline 8 & 0.736 & 6.339 & 2.0739 & Valid \\
\hline 9 & 0.463 & 3.045 & 2.0739 & Valid \\
\hline 10 & 0.845 & 9.213 & 2.0739 & Valid \\
\hline 11 & 0.78 & 7.267 & 2.0739 & Valid \\
\hline 12 & 0.789 & 7.488 & 2.0739 & Valid \\
\hline 13 & 0.846 & 9.251 & 2.0739 & Valid \\
\hline 14 & 0.477 & 3.164 & 2.0739 & Valid \\
\hline 15 & 0.345 & 2.143 & 2.0739 & Valid \\
\hline 16 & 0.572 & 4.066 & 2.0739 & Valid \\
\hline 17 & 0.717 & 5.997 & 2.0739 & Valid \\
\hline 18 & 0.75 & 6.611 & 2.0739 & Valid \\
\hline 19 & 0.48 & 3.190 & 2.0739 & Valid \\
\hline 20 & 0.918 & 13.497 & 2.0739 & Valid \\
\hline
\end{tabular}

Dari tabel 3 dan 4 hasil uji validitas menggunakan MS.Excel dilakukan pada 24 siswa, uji validitas variabel y yaitu 20 soal pertanyaan. Soal yang dinyatakan valid 19 soal pertanyaan dan tidak valid 1 soal pertanyaan.

\section{Uji Reliabilitas}

Dalam menguji reliabilitas instrument penelitian ini, penulis menggunakan rumus Cronbach's $\operatorname{Alpha}(\alpha)$ :

$$
\begin{aligned}
& r_{11}=\left(\frac{n}{n-1}\right)\left(1-\frac{\sum S_{i}^{2}}{S_{t}^{2}}\right) \\
& r_{11}=\left(\frac{17}{17-1}\right)\left(1-\frac{7.838}{59.824}\right)=0.931
\end{aligned}
$$

Koefisien reliabilitas yang dihasilkan, di interpretasikan dengan menggunakan tabel kriteria dari Guilford ${ }^{16}$ yaitu:

Tabel 5. Klarifikasi Koefisien Reliabilitas

\begin{tabular}{|c|c|}
\hline $\begin{array}{c}\text { Koefisien realibitas } \\
(\mathbf{r})\end{array}$ & Interpretasi \\
\hline $0,00 \leq \mathrm{r}<0,20$ & Sangat Rendah \\
$0,20 \leq \mathrm{r}<0,40$ & Rendah \\
$0,40 \leq \mathrm{r}<0,60$ & Sedang/Cukup \\
$0,60 \leq \mathrm{r}<0,80$ & Tinggi \\
$0,80 \leq \mathrm{r}<1,00$ & Sangat Tinggi \\
\hline
\end{tabular}


Dari hasil perhitungan tersebut, maka koefisien reliabilitas sebesar 0,931 sehingga termasuk kategori tinggi.

Setelah melakukan uji reliabilitas media audio visual, kemudian maharoh istima' atau variabel $\mathrm{y}$, didapatkan hasil uji validitas dari 20 soal terdapat 1 soal yang tidak valid, maka untuk pengolahan reliabilitasnya hanya 19 soal tersebut yang diolah.

Hasil yang diperoleh menggunakan rumus Cronbach's Alpha $(\alpha)$ :

$$
\begin{aligned}
& r_{11}=\left(\frac{n}{n-1}\right)\left(1-\frac{\sum s_{i}^{2}}{S_{t}^{2}}\right) \\
& r_{11}=\left(\frac{19}{19-1}\right)\left(1-\frac{10.164}{89.432}\right)=0.941
\end{aligned}
$$

Dari perhitungan tersebut di dapati hasil reliabilitas 0.941 maka koefisien termasuk kategori tinggi.

\section{Uji Kesukaran Soal}

Uji tingkat kesukaran soal merupakan cara yang digunakan untuk mengukur tingkat suatu soal, apakah soal tersebut dikatakan mudah, sedang, atau sukar. Berikut daftar uji soal dengan kategori tingkat kesukaran.

Tabel 6. Hasil Taraf Kesukaran Soal

\begin{tabular}{|l|l|l|}
\hline \multicolumn{1}{|c|}{ Interpretasi } & \multicolumn{1}{|c|}{ Jumlah Item } & \multicolumn{1}{c|}{ Nomor Item Soal } \\
& \multicolumn{1}{|c|}{ Soal } & \\
\hline Mudah & 16 Soal & $, 2,4,6,7,8,9,10,11,12,13,15,16,17,18,19,20$ \\
\hline Sedang & 1 Soal & 1 \\
\hline Sukar & - & - \\
\hline
\end{tabular}

\section{Analisis Data}

Dalam penelitian ini, peneliti melakukan pengujian terhadap hipotesis yang telah diajukan sebelumnya yaitu: “Ada pengaruh media audio visual terhadap maharoh istima' Bahasa Arab.” Adapun langkah-langkah yang dilakukan peneliti yaitu sebagai berikut.

\section{Data Nilai}

Berikut ini adalah data nilai yang diperoleh siswa setelah mengerjakan soal.

Tabel 7. Data Nilai Siswa 


\begin{tabular}{|c|c|c|c|}
\hline NO & NAMA & $\begin{array}{c}\text { Media } \\
\text { Audio } \\
\text { Visual } \\
(\mathbf{X})\end{array}$ & $\begin{array}{l}\text { Maharoh } \\
\text { istima' } \\
\text { (Y) }\end{array}$ \\
\hline 1. & Dela Nurul Aulia & 81 & 86 \\
\hline 2. & Didan Bahtiar & 62 & 67 \\
\hline 3. & Didin Muadin & 90 & 93 \\
\hline 4. & Diki Zulfikar & 81 & 86 \\
\hline 5. & Fikri Fauzi P & 55 & 63 \\
\hline 6. & Hasni Aulia Alifah & 80 & 85 \\
\hline 7. & Imam Mujahidin & 61 & 71 \\
\hline 8. & Irfan Setiawan & 60 & 68 \\
\hline 9. & Jamil Muttaqin & 75 & 85 \\
\hline 10. & Jasmin nazwa Halika & 65 & 75 \\
\hline 11. & Khusi Ilma Na'afilah & 80 & 85 \\
\hline 12. & Laisa Cyntia P & 80 & 90 \\
\hline 13. & Nabil Aufa P.R & 58 & 63 \\
\hline 14. & Nurlaila Jihadah & 76 & 82 \\
\hline 15. & Paldi Yanwar Maulana & 62 & 73 \\
\hline 16. & Rihma Aulia Tazkya & 75 & 78 \\
\hline 17. & Rubby Aziz Zaura Kamal & 65 & 71 \\
\hline 18. & Salman Nuri Naufal & 97 & 97 \\
\hline 19. & Salwa Nurul Aini & 80 & 81 \\
\hline 20. & Selpi Khoirunnisa & 61 & 65 \\
\hline 21. & Siti Nizma Muthmainnah & 76 & 77 \\
\hline 22. & Srilasmi Puja Lestari & 77 & 81 \\
\hline 23. & Zulfa Azkia & 96 & 96 \\
\hline 24. & Yaris Pebrian & 63 & 67 \\
\hline
\end{tabular}

\section{Uji Wilcoxon}

Berikut ini pengujian Wilcoxon menggunakan SPSS 25.00

\begin{tabular}{|l|l|r|r|r|}
\hline \multicolumn{7}{|c|}{ Ranks } \\
\hline \multicolumn{2}{|c|}{} & \multicolumn{1}{c|}{ N } & Mean Rank & \multicolumn{1}{c|}{ Sum of Ranks } \\
\hline $\begin{array}{l}\text { Maharoh_Istima } \\
\text { Media_Audio_Visual }\end{array}$ & Negative Ranks & $0^{\mathrm{a}}$ & .00 & .00 \\
\cline { 2 - 6 } & Positive Ranks & $22^{\mathrm{b}}$ & 11.50 & 253.00 \\
\hline
\end{tabular}




\begin{tabular}{|l|r|r|r|}
\hline & Ties & $2^{\mathrm{c}}$ & \\
\cline { 2 - 4 } & Total & 24 & \\
\hline a. Maharoh_Istima $<$ Media_Audio_Visual \\
b. Maharoh_Istima $>$ Media_Audio_Visual \\
\hline c. Maharoh_Istima $=$ Media_Audio_Visual \\
\hline
\end{tabular}

Berdasarkan output "Test Statistics", diketahui Asymp.Sig. (2-tailed) bernilai 0.000. Karena nilai 0.000 lebih kecil dari < 0.05, maka dapat disimpulkan bahwa hipotesis diterima. Artinya ada pengaruh media audio visual terhadap maharoh istima' bahasa Arab pada kelas VIII MTs Persis 79 Rajapolah.

\section{Kesimpulan}

Berdasarkan pemaparan di atas maka dapat disimpulkan beberapa hal sebagai berikut:

Media audio visual adalah alat perantara yang digunakan untuk menyampaikan konsep pembelajaran yang dapat ditangkap oleh indra pendengaran dan pandangan, sehingga memudahkan siswa dalam mempelajari bahasa Arab untuk meningkatkan pembendaharaan kosakata, percakapan dan maharoh istima'.

Setelah melakukan test soal kepada siswa, didapati hasil perhitungan menggunakan SPSS Uji Wilcoxon yang menunjukkan "Test Statistics", diketahui Asymp.Sig. (2-tailed) bernilai 0.000. Karena nilai 0.000 lebih kecil dari < 0.05, maka dapat disimpulkan bahwa hipotesis diterima. Artinya ada pengaruh media audio visual terhadap maharoh istima' bahasa Arab pada kelas VIII MTs Persis 79 Rajapolah.

Selama pembelajaran terdapat kendala-kendala yang dihadapi. Untuk penggunaannya harus tersedia elektronik yang cukup mahal, di antaranya kendala yang dihadapi siswa adalah kemampuan menggunakan elektronik yang belum cukup. Kendala bagi pengajar adalah alat elektronik yang mahal, seperti proyektor, laptop dan listrik yang selalu menyala agar belajar mengajar berlangsung dengan baik. 
Pengaruh Media Audio Visual Terhadap Pemahaman Maharoh Istima' Bahasa Arab

\section{Daftar Pustaka}

Arikunto dan Suharismi, Prosedur Penelitian Suatu Pendekatan Praktek Jakarta: Rineka Cipta, 2008

Azhar, Arsyad. Media Pembelajaran. Jakarta: Raja Grafindo Persada, 2010

Bahri, Syaiful dan Zain Aswin. Strategi Belajar Mengajar. Jakarta: Ciputat Press, 1997

Gulo, W. Strategi Belajar Mengajar. Jakarta: Grasindo, 2002

Hamid, Abdul et al. .Pembelajaran Bahasa Arab: Pendekatan, Metode, Strategi, Materi, dan Media. Malang: UIN-Malang Press, 2008

Madkur, Ali Ahmad. Tadris Funun al-Lughah al-Arabiyah. Kairo: Dar el-Fikr al-'Araby, 2006

Pusat Bahasa Departemen Pendidikan Nasional, Kamus Besar Bahasa Indonesia. Jakarta : Balai Pustaka, 2006

Sahatah, Hasan. Ta'lim al-Lughoh al- 'Arabiyah baina an-Nadhoriyah wa at-Tathbiq. Bayrut: ad-Dar al-Misriyah al-Libnaniyah, 1993

Setyawan, Cahya Edi. "Konsep Landasan Teori Dan Rancangan Silabus Pembelajaran Maharah Istima Di Perguruan Tinggi” Jurnal Komunikasi dan Pendidikan Islam, Volume 7, Nomor 1, Juni 2018

Thuaimah, Rusydi Ahmad. al-Marja' fi Ta'lim al-Lughoh al-'Arabiyah li an- Natiqiina bi Lughot Ukhro. Riyadh: Jami'ah Umm al-Quro Ma’had al-Lughoh al-'Arabiyah Wahdah al-Buhuts wa al-Manahij Silsilah Dirosat fi Ta'lim al-'Arabiyah, 1986

Yusuf, Tayas dan Saiful Anwar. Metodologi Pembelajaran dan Bahasa Arab. Jakarta:, PT. Grafindo Persada, 1995

Zulhannan, Teknik Pembelajaran Bahasa Arab Interaktif. Jakarta: PT Raja Grafindo Persada, 2014 